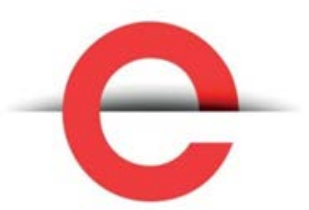

U T S

e PRE S S

Cosmopolitan

Civil Societies: an

Interdisciplinary

Journal

Vol. 9, No. 1

2017

(C) 2017 Jae-Eun Noh. This is an Open Access article distributed under the terms of the Creative Commons Attribution 4.0 Unported (CCBY 4.0) License (https:// creativecommons.org/ licenses/by/4.0/), allowing third parties to copy and redistribute the material in any medium or format and to remix, transform, and build upon the material for any purpose, even commercially, provided the original work is properly cited and states its license.

Citation: Noh, J. 2017. The role of NGOs in Building CSR Discourse around Human Rights in Developing Countries. Cosmopolitan Civil Societies: an Interdisciplinary Journal. 9(1), 1-19.

http://dx.doi.org/10.5130/ccs.v9i 1.4826

ISSN 1837-5391|Published by UTS ePRESS|https://epress. lib.uts.edu.au/journals/index. php/mcs
REFEREED PAPER

\section{The Role of NGOs in Building CSR Discourse around Human Rights in Developing Countries}

\author{
Jae-Eun Noh \\ University of Queensland, Australia
}

Corresponding author: Jae-Eun Noh, International Development, University of Queensland, St Lucia, Queensland 4072, Australia. jaeeun.noh@uqconnect.edu.au

DOI: http://dx.doi.org/10.5130/ccs.v9i1.4826

\begin{abstract}
As a response to increasing influences of transnational corporations (TNCs) over the lives of the poor, development NGOs have tried to promote TNCs' responsibility in cooperative ways: partnership in development projects and voluntary regulations. Notwithstanding some degree of success, these cooperative ways have failed to bring fundamental changes to TNCs. This paper outlines the limitations of the mainstream corporate social responsibility (CSR) and suggests a human-rights-based approach as an alternative to the current CSR discourse. Reframing the CSR discourse with human rights involves collective actions of grassroots people. People in developing countries have been neglected in the CSR discourse; however, they have power to change the discourse as labourers, consumers and citizens. Drawing on case studies, this article suggests that NGOs should support grassroots people in constructing collective visions in terms of human rights, facilitating participatory and empowering process, and maximising power through creating information flow and building global networks.
\end{abstract}

\section{Keywords}

Corporate Social Responsibility (CSR), Corporate Accountability, Grassroots social movements, Developing countries, Development NGO, Advocacy 


\section{Introduction}

With the rapid change accompanied by globalisation, the increasing influences of transnational corporations (TNCs) over people's lives in developing countries have raised a question of what should be done by development non-governmental organisations (NGOs). The number of TNCs has dramatically increased from 7,000 in 1970s to 78,000 in 2007, and they exert their power throughout the world with more than 780,000 branches (Madeley 2008). Despite some positive functions, TNCs are generally criticised for their negative influences on the livelihood of local people (Fox 2004; Madeley 2008). This has led to the promotion of corporate social responsibility (CSR) since 1990s (Karp 2014). Although CSR is diversely named and defined (Andrews 2013), the European Commission (EC) states that CSR is 'a concept whereby companies integrate social and environmental concerns in their business operations and in their interaction with their stakeholders on a voluntary basis' (EC 2001, p.6 in Hond et al. 2007).

Following this definition, development NGOs have promoted CSR through establishing codes of conduct, granting certificates to help consumers make informed choices, operating development programs in partnership, and conducting performance measures and social audits (Fox 2004; McIntosh 2003). To some degree, these programs have provided a vehicle to improve corporate practices. However, NGO programs in the name of CSR have not been responsive to local people's needs and voices (Andrews 2013). In addition, few studies show that TNCs' CSR has successfully encompassed the social and environmental concerns that people in developing countries have (Gilberthorpe \& Banks 2012). This is possibly because of the difficulty in measuring outcomes such as the social and environmental benefits to developing counties (Thekdi 2016). This paper would rather locate the reason for limited success in the way CSR discourse is constructed.

CSR discourse has been dominated by Northern players (Andrews 2013; Fox 2004; Idemudia 2011). It has centred on corporations' voluntary actions and consumers' power in developed countries (Frynas 2005). Therefore, the majority of international development NGOs have tried to influence companies and citizens in the developed world. Their inattention to people's agency in developing countries resulted in ineffective and inappropriate CSR programs (Gilberthorpe \& Banks 2012; Idemudia 2011) and raised questions about NGO legitimacy (Arenas et al. 2009). This paper notes that people in developing countries have potential power as labourers, consumers and citizens to influence TNCs' practices. This can open up the possibility of grassroots social movements for CSR (Andrews 2013; Bond 2008). NGOs can find their roles as facilitators and advocates for grassroots social movements, an approach suggested as most effective in holding TNCs accountable in the context of developing countries (Jamali 2014).

Human rights have been central to NGO involvement in grassroots social movements. Human rights can have universal and normative appeal (Cornwall 2007). However, talk of a human rights framework raises a debate about its Western centrism (Nyamu-Musembi \& Musyoki 2004) and its reference to legal and professional knowledge (Hickey \& Mitlin 2009). As a result, NGOs' advocacy has been criticised as an 'elite activism' (Unerman \& O'Dwyer 2006) without representation and participation of people living in developing countries. 
This paper suggests that CSR discourse should be shaped around human rights by those who are affected by TNCs operating in developing countries. In such a discourse shift, development NGOs can take on roles in promoting human-rights-based discourse for corporate accountability by facilitating grassroots movements in developing countries. Integrating human rights standards and principles into CSR discourse can be a way of addressing the problems of the current CSR discourse: CSR remains voluntary to TNCs; the agency of people in developing countries is not seriously considered; and NGOs have lost their representativeness and legitimacy in their CSR-related programs. This alternative approach to CSR discourse can open a new opportunity to effectively hold TNCs to account for their human rights violations. Reframing CSR with human rights can also enhance NGO legitimacy (Middleton \& Pritchard 2013).

\section{Scope and Overview of the Paper}

The purpose of this paper is to explore how the human-rights-based CSR can be an alternative to the present CSR discourse and what NGOs can do to shape CSR discourse around human rights as a way of making corporations accountable for people in developing countries. 'NGOs' here refers to development NGOs which work across the world and mostly originate in developed countries.

This paper is structured as follows. The first section discusses how theories on discourse and social movements are relevant to this research. The second section outlines the problems of the current CSR discourse and NGO activities in it. This review of CSR discourse leads to the necessity for an alternative discourse, a human-rights-based approach to CSR. In the third section, case studies demonstrate how people in developing countries exercise their power as consumers, labourers and citizens and what kinds of limitations remain in grassroots-led social movements. The last section explores how NGOs can play a role in overcoming identified limitations of grassroots social movements by reframing CSR with human rights perspective.

\section{Locating CSR in theories on discourse and social movement}

CSR is conceptualised in this paper as 'discourse', which defines what CSR is and how it should be. The concept of a 'discourse' is mainly informed by early work of Foucault. Foucault (1972) theorises discourse as a system of constituting and presenting knowledge through power. Looking at CSR through the lens of discourse involves analysis of 'knowledge and power' from Foucault's (1978) perspective. The meaning of knowledge and power needs to be articulated first in order to clarify concepts referred to in this paper. With regard to 'knowledge', Foucault holds that the objects of knowledge are decided by dominant discourse (Fairclough 1992). 'Power' is defined as 'a way in which certain actions modify others' (Foucault 1982: 788). Foucauldian power is different from traditional concepts of power. Power is not possessed but exercised, and not necessarily oppressive but possibly productive (McHoul \& Grace 1993; Schirato 2012). To Foucault, power is multi-directional, relational and neutral (Fraser 1989; Joseph 2004; Wetherell et al. 2001). Mechanisms of power produce knowledge and knowledge reinforces exercises of power (Foucault 1980). In other words, knowledge and power influence and shape each other (McHoul \& Grace 1993). 
Discussing interactions between knowledge and power, Foucault's later work suggests the existence of agency in his concepts of 'the subject' and 'resistance', although the focus of his argument is not apparently agency but discursive practices (Fairclough 1992; McHoul \& Grace 1993). 'The subject' is described as an entity with self-awareness and capability to make a choice and 'resistance' implies the multiplicity of discourses. Context is suggested as 'the conditions of existence of a discourse' (Foucault 1972: 38), but also agency is located and shaped in context. Informed by Foucault's concepts, this paper acknowledges that CSR discourse is understood as interwoven with knowledge and power. It also draws attention to the ways in which CSR discourse is challenged and re-constructed by interaction between local agency and context.

In CSR discourse, a significant body of literature discusses drivers for and outcomes of CSR programs in terms of economic and social benefits to TNCs. For example, TNCs incorporate CSR in expectation of customer loyalty, improved brand image, better record in staff recruitment and retention, stability without strikes and adoption of innovative ideas (Aguirre 2008; Fox 2004; Hond et al. 2007). Effects of CSR are assessed by customer evaluation, reputation of company (Aguinis \& Glavas 2012) and increased employee morale (Subba \& Rao 2016). This suggests that CSR initiatives have been a strategy to maintain or strengthen corporate power. With a focus on responsibilities, Carroll's 'the pyramid of CSR' has been widely used to explain the nature of CSR and corporate priorities in order 'economic responsibilities to be profitable, legal responsibilities to obey laws, ethical responsibility to do the right things, and philanthropic responsibilities to be a good corporate citizen' (1991, p.42). Schwartz and Carroll (2003) add another dimension of stakeholders to this pyramid model: economic responsibilities required by global capitalism, legal responsibilities required by global stakeholders, ethical responsibilities expected by global stakeholders, and philanthropic responsibilities desired by global stakeholders (2003, p.504). However, some studies question this model's universal applicability, drawing attention to contextual influences. Philanthropic activities are observed to be more prevalent and prioritised in developing countries than legal and ethical ones (Visser 2006). This difference is explained by the reality of extreme poverty and people's expectation in developing countries (Jamali 2014). Another reason for this may possibly be the lack of a consensus about legal and ethical obligations of TNCs. Setting higher legal and ethical standards can be a form of resistance to philanthropy-dominant CSR discourse and to transnational corporate power.

This paper gives attention to grassroots mobilisation for social movements in developing counties as a strategy to contest and reshape TNCs' CSR. There are two main theories of social movement mobilisation: resource mobilisation and grassroots mobilisation (Morris \& Mueller 1992). Resource mobilisation theory suggests that professional organisations' ability of mobilising available resources and building tactics is the key to the success of social movements. Habermas (2001) argues that NGO-driven social movements can lead to transformative changes by raising citizens' awareness about unjust globalisation. Tarrow (1994, 2005) places an emphasis on a globally accepted framework and political opportunities, which increase the likelihood of success by reducing the cost for collective action. Meanwhile, grassroots mobilisation theory, which emerged as a counter-argument to resource mobilisation theory, emphasises the importance of agents who actively participate in 
constructing social meanings. It holds that grassroots movements should be understood as a process of creating new collective meanings based on their daily life (Escobar 1995).

In this paper, grassroots mobilisation theory is used to support the argument that local people in developing countries can exert their power through collective movements as agents of change. At the same time, the resource mobilisation theory highlights the roles of development NGOs as facilitators to support grassroots movements. NGOs are expected to supplement resources and open up opportunities by making a link with macro socio-political environment (Tarrow 1994; 2005). In addition, NGOs can assist local people in constructing collective values in order to overcome the weakness of the resource mobilisation theory.

\section{CSR strategies employed by development NGOs}

NGOs have worked to promote CSR mainly in two ways: collaborating in development projects and urging corporations to adopt voluntary regulations. These activities have achieved some level of success in influencing corporations' behaviours. However, some limitations and inherent problems are found. This section examines why the existing CSR is not so effective and how these cooperative ways can threaten the identity and legitimacy of NGOs.

\section{Cooperation with corporations as development partners}

Corporations and NGOs meet each other's needs through cooperative partnership in the name of CSR. Corporations are interested in working with NGOs because of their good image and experience in developing countries, where more business opportunities are found (Fowler 2000). Corporations also tend to regard NGOs as a like-minded partner in terms of opposition to state intervention as both are non-governmental actors (Lindenberg \& Dobel 1999). For NGOs, corporations have the potential to be big donors. Due to declining official aid with increasing resistance from tax payers (Fowler 2000), NGOs have turned their eyes to corporations, especially to big-sized transnational ones. Lindenberg and Bryant (2001) give an example of a partnership between an NGO (CARE international) and a TNC (Starbucks): CARE provided Starbucks with donation-with-purchase items and opportunities for voluntary activities and child sponsorship; Starbucks funded some development projects and offered consulting services and business-related staff training to CARE.

This case suggests that corporations' involvement in projects can make NGOs trade their core values for funds. Funded-projects are likely to be tailored to suit corporations' needs such as tangible benefits to their brand image. In addition, non-project cooperation such as staff training or management consultation tends to change an NGOs' culture (Lindenberg \& Dobel 1999). NGOs adopt business management tools and the mind-set attached to the tools (Fowler 2005). This 'business-like' change influences how development is conceptualised and how development issues are tackled (Panitch and Leys 2003). When a business culture replaces a value-oriented culture of development NGOs, the principle of efficiency takes priority over social justice and empowerment.

\section{Promoting voluntary regulations}

NGOs have tried to hold corporations responsible through promoting certification system and codes of conduct (Edwards and Gaventa 2001; Fox 2004; McIntosh 2003). For instance, 
about 13\% (32 out of 246 companies in OECD member countries) of codes were adopted through NGO pressure and these codes contained far greater accountability for the public than internally issued codes (OECD 2001). Despite some improvement in corporate practice, these voluntary regulations reveal several limitations.

Adopting a regulatory scheme does not guarantee corporations' ethical and responsible practice. The ISO (International Organisation for Standardisation) 26000 for social responsibility and the United Nations Global Compact (UNGC) are representative international standards. The alignment with the ISO standards and the UNGC is proudly publicised by Nestlé (Nestlé Public Affairs 2007). However, Nestlé was heavily criticised for causing many deaths by promoting infant formula (International Council on Human Rights Policy 2002; Waddock 2009). Codes of conduct are minimal and they outline corporate responsibility in a selective and subjective way. ILO (International Labour Organisation)'s evaluation also shows that two thirds of codes of conduct do not stipulate social and cultural rights in line with international standards (Aguirre 2008). An empirical study also suggests that companies with codes of conduct are not significantly better in terms of working condition. (Lindholm et al. 2016). This is basically because of the voluntary nature of these international guidelines.

Many of these standards, even not all, are set in the absence of local people's participation. (Yu 2009). Though people in developing countries are directly and indirectly influenced by corporate behaviours, their opinions are not heard in the process of establishing so called 'international' standards. Furthermore, the responsibility involved in compliance with a regulative system is often transferred by a supply chain to small and medium companies in developing countries (Blowfield 2005).

Voluntary regulations do not impose any fundamental change on corporations. Certification and codes of conduct help corporations to position themselves where they are safe from criticism and where they can expand to a differentiated market (Conroy 2001). Standards are neither ambitious enough nor enforceable. Voluntary regulations are not comprehensive enough to embrace various aspects of corporate practices (Blowfield 2005).

\section{Common limitations in existing approaches}

The current strategies have fundamental and inherent limitations which risk NGO legitimacy. Legitimacy is defined as a 'generalised perception or assumption that the actions of an entity are desirable, proper, or appropriate within some socially constructed system of norms, values, beliefs, and definitions' (Suchman 1995, p. 574 in Hond et al. 2007). Existing CSR programs have been carried out without consultation and participation of vulnerable people whom NGOs work for. Present efforts to enhance CSR are based on the assumption that raised awareness of consumers and citizens in developed countries can change corporations.

Furthermore, more fundamental questions about the role of NGOs can be raised. What is the role of development NGOs in a global and neoliberal world? The concept of CSR highlights the necessity of an incremental reform of current business practice, but does not question capitalism or globalism itself (Blowfield 2005). This paper does not suggest that a sweeping reform or a radical denial of capitalism is the only answer. However, NGOs are required to do something beyond delivering services with funds donated by corporations and making vulnerable people adjust to the present world order. In short, these types of CSR 
practices simply add moral components to capitalism, which produces structural problems of social and environmental injustice (Blowfield 2005).

It is hard to determine if NGOs' current activities for enhancing corporate responsibility are either important or useful. In addition, NGOs' engagement with TNCs is getting diversified. This is why NGOs are perceived by corporations as having mixed images of fundraiser, partner and critic at the same time (Arenas et al. 2009). Acknowledging the limitations of CSR activities as discussed above, some development NGOs try to create alternatives to the cooperative CSR. For example, they have launched campaigns against corporate behaviour such as tax avoidance and land grabbing under the overarching framework of 'tax justice' and 'food security' respectively (Molina-Gallart 2014). However, such types of engagement relate to only particular sectors and still target Northern shareholders and consumers seeking to influence on TNCs' reputation and sales.

\section{An alternative: Human-rights-based approach to corporate accountability}

I hereby suggest that a human-rights-based approach to corporate accountability can be an alternative to the current CSR discourse. Meta-analysis of NGO perceptions of CSR indicates that NGOs place a high priority on human rights (Skouloudis et al. 2015). A human-rightsbased approach can shift CSR discourse from charity to entitlement, from moral and discretionary duties to legally binding duties, and from voluntary practices to enforceable requirements (Karp 2014; Middleton \& Pritchard 2013). There are examples that human rights NGOs brought justice to TNCs' wrongdoings abroad using the national legal framework in the USA (Karp 2014). The word 'accountability' connotes responses to an external force unlike 'CSR', which is preferred by corporations as it emphasises a voluntary commitment by internal push (Kovacs 2006). Both 'human rights' and 'accountability' suggest that people have a right to make demands and corporations have an obligation to meet the demands (Newell et al. 2006).

Introducing human rights to CSR can raise a question if human rights principles can be applied to TNCs. Karp (2014) answers this question by drawing on the analysis of international human rights law and polices that TNCs can hold human rights responsibilities despite their differences from the states, the principal duty bearers in human rights discourse. Then a more relevant question would be how to make TNCs accountable to people in developing countries. Noticeable changes in TNCs have occurred from the pressure of civil society, including local communities (O'Faircheallaigh \& Ali 2008). Likewise, Rathert (2016) holds that human-rights-guided CSR can be considered by TNCs when stakeholders pressure them to avoid human rights violations. Given that external pressure is of critical importance, this paper pays attention to grassroots social movements, which are believed to be the key to meaningful changes (Tarrow 2005).

The increased capacity of local people and the development of ICT open up ample opportunity for the success of grassroots social movements. ICT helps them gain access to a lot of information they need. In addition, quicker and cheaper transportation and communication enable them to make their voices heard (Lewis \& Wallace 2000). The language barrier is also breaking down with higher education and increased exposure to English (Clark 2003). All of these raise the possibility of overcoming the geographical restrictions and limited influence of social movements initiated by local people. 


\section{Potential power of grassroots social movements}

The analysis of the reasons behind corporate changes helps our understanding of how social movements can work towards promoting corporations' accountability. Of all drivers discussed in earlier sections taken together, the main driving force is the threat of losing sales. Corporations take their responsibility seriously when they need to respond to external pressures such as negative reputation, boycotts, media coverage and demonstrations (Aguirre 2008; Fox 2004; OECD 2001), which may impact on their sales record in consequence.

Local people can pressure corporations into taking responsibility for the environmental, social and economic impacts of the corporate behaviours on the communities. Even though individuals in developing countries may not have significant bargaining power, collective actions have brought direct changes in corporate behaviour (Unerman \& O'Dwyer 2006). They can have influential power through power mechanisms as follows: 1) wage increase, slowdown, strike, and protest as labourers (Yu 2009); 2) boycott and protest as consumers (Caruana \& Chatzidakis 2014); and 3) boycott, campaign, protest, and lawsuit as citizens (Bond 2008). These collective actions basically aim to cause a profit plunge. The following sections demonstrate how local people have exercised their collective power as labourers, consumers and citizens. The examples discussed illustrate the potential of grassroots-driven social movements and some lessons for more successful movements.

\section{Power as labourers}

Workers would be the group most directly influenced by TNCs' operation in developing countries. Some corporations prefer hiring female employees as their personal network is crucial for selling products as shown in the case of Avon, a cosmetics seller (Dolan \& Scott 2009) and as they are usually less paid than male workers. TNCs have used CSR as a way to regulate labour abuse occurring in their supply chain, but have failed to ensure participation of labourers in the process of CSR (Yu 2009).

Gaventa and Tandon (2010) introduce a case study of Bangladesh to demonstrate active participation and collective power of female workers in garment industry. Most female garment workers were from poor families in remote rural areas. Becoming a factory worker is one of their limited options. These factory workers had no representative unions and no knowledge of Bangladeshi labour law. Though female workers were not aware of their rights, at least they knew that they had been treated unfairly by export garment factories with no minimum wage, delayed payment, unsafe and unhealthy workplace, and exploitative working conditions. Proactive collective actions carried out by women labourers in the garment industry succeeded in drawing unprecedented public attention nationally and internationally, and in bringing changes to corporates.

A noteworthy factor in this case is that labourers are not struggling only with corporations. They face lack of governmental support and public sympathy, because their claims for labourers' rights are seen as a threat to the acquisition of foreign currencies or as an inordinate demand, since their working conditions seem relatively better than those in the domestic workplace. Mahmud in Thompson and Tapscott (2010) points to a further reason for mobilisation difficulties, noting that young female workers were not well educated and were raised in a conservative rural area before their joining a factory in search of work. It 
must be difficult for low-ranked girls to mobilise their collective actions, being under job threat in a labour-surplus country and in a severely unbalanced worker-employer relationship (Thompson \& Tapscott 2010). Put another way, the case of Bangladeshi female workers reveals some weaknesses as well as highlighting labourers' potential power, as it failed to maintain the momentum and win the support of the society. The factory collapse in April 2013, which was recorded as the worst industrial disaster in the world this decade with a death toll of about 1,200 , corroborates the perpetuation of the global supply chain which drives low-income workers into hazardous working environments (Gifford \& Ansett 2014).

\section{Power as consumers}

Nowadays, corporations take notice of increased purchasing power and the large volume of purchasers in developing countries, creating a marketing strategy named as BOP (bottom / base of the pyramid) (Silverthorne 2007). While potential consumers in developing countries are continuously persuaded into buying things manufactured by TNCs, they are more vulnerable to market injustice than consumers in developed countries. Consumer rights movements have played a role in promoting corporate accountability with wider constituency than labourers' movements and with a link to global movements. Hilton (2007) shows the history of consumer movements in Malaysia and their accomplishments. In the absence of a strong civil society because of governmental restrictions, consumerism could expand its areas from raising awareness on consumer rights and enacting a protective law to setting a broader human rights agenda and raising environmental issues, with the appearance of non-political movements. Consumerism in developing countries is differently interpreted as an access to the basic necessities, unlike in advanced economies where it is understood as a range of choices (Clark 2003). So consumer rights movements could draw extensive public attention as they speak for everybody's survival rights. The Consumers' Association of Penang actively spread the concept of consumer rights in Malaysia and raised its voice internationally to protect consumers from harmful pesticides (Hilton 2007). The Association also succeeded in bringing a Japanese company to court and in claiming the company's legal responsibility for water pollution (Clark 1991).

Despite some extent of success, the Malaysian consumer movement has surrendered its influential position to other forms of social movements and has not been sustained because of its weakness of being close to the Government (Hilton 2007). The growth of consumer movements was attributed to their apolitical nature. However, government friendliness could not be compatible with the identity of people's movement. This case study suggests the importance of having independent and alternative entities as social movement organisations.

\section{Power as citizens}

Noticeably, some social movements against corporations have occurred over resources in combination with indigenous people's rights or environment movement. The Indian people's fight with the Coca-Cola Company provides an example (Madeley 2008). The company's factory in Kerala, India, needed plenty of water to produce Coca-Cola. Coca-Cola's vast quantities of water consumption brought about chronic water shortage for drinking and agriculture. Furthermore, the operation of the plant polluted water and land. Hence local 
people organised a collective struggle for their right to sovereignty over natural resources and their environment in order to regulate the practice of the company. Finally, the factory had to close as its license was annulled by the Council (Madeley 2008).

Thompson and Tapscott (2010) cite South African citizens' legal actions as an example of popular mobilisation. In this case, local residents of two communities made a claim for compensation as they had suffered from respiratory diseases caused by a British mining company. Interestingly, there was a marked difference between two communities in terms of empowerment: one with stronger community-based organisations and better network could be empowered through the legal process, while the other community was dependent on foreign law firms.

In short, these two cases of India and South Africa illustrate the power of mobilised people, and at the same time, show that empowering local communities and taking historical and social contexts into consideration is important for successful movements.

\section{Weakness of local collective actions}

The above-mentioned cases commonly demonstrate the potential power of local people to influence corporations. However, some limitations are found. These collective actions tend to concentrate on specific issues and last for a short span of time (Nyamugasira 1998). In many cases, the common objective was economic compensation (Thompson \& Tapscott 2010). Such a short economic interest-led activity does not accord with the definition of a social movement, which is characterised by sustainability and solidarity (Tarrow 1994). Without embracing diverse agendas (Borras et al. 2008), collective actions were taken by only a handful of people with direct interests. Regarding sustainability, local-driven movements frequently had difficulty in maintaining activities because of poor management and decreased morale (Madeley 2008). Moreover, many collective actions have failed in gaining global attention and support. Since their actions were too localised, the impact on corporations was limited.

On the other hand, the impact of local movements should be assessed in terms of empowerment and sustainability. Questions are raised about the distribution of acquired power and the sustained impact of empowerment. Internal power differences have often been overlooked (Borras et al. 2008). It is necessary to look into whose inclusion and whose interests are guaranteed (Fowler 2007). In many cases, the result of collective actions was slightly increased income, which might hamper the further challenge of addressing underlying problems (Sen \& Edwards 2000). Due to such limitations, collective actions initiated by local people could not bring about significant and fundamental change to corporate practices.

\section{Roles of NGOs in grassroots activism for human-rights-guided CSR}

In advocacy, NGOs have positioned themselves as intermediaries between the poor in developing countries and the powerful in developed countries. Such intermediary roles can be minimised by information technology and increased competence of local people (Clark 2003; Lewis \& Wallace 2000). However, NGOs are still expected to perform a role with their comparative advantages, which are helpful to overcome the shortcomings of local movements 
identified in the former section. Issues concerning the small scale, limited impact, lack of comprehensive goals and nominal empowerment should be addressed for social movements for corporate accountability to be effective and sustainable. NGOs can contribute to grassroots movements with their resources, broad network and reputation. In particular, development NGOs with a human rights orientation can enhance corporate accountability by generating human rights-guided visions, building participatory and empowering process, and maximising power through global network and information technology.

\section{Role 1 - Generating visions and values around human rights}

A social movement itself is not an end. It is more important to build alternative values and a healthy community through collective actions. NGOs can support grassroots efforts to develop social meanings and alternative visions in the process of developing social movements (Rahman 1993). This paper suggests that 'human rights' should be core values in an alternative approach to TNCs' CSR. A human rights framework helps to set common standards to assess corporate practice, and human rights language can be powerful (International Council on Human Rights Policy 2002). The introduction of a human-rightsbased approach can bring about a change in a relationship between TNCs and people in developing countries. This change is reflected in the shift in language from giver to duty bearer and from receiver to right holder (Boesen \& Martin 2007). Case studies discuss different, but often interrelated, types of human rights including the right to nondiscrimination, right to work, right to safety and security, right to sustainable environment (Middleton \& Pritchard 2013), right to participation, right to freedom of association (Yu 2009), right to food, right to freedom of expression and right to privacy (Karp 2014). However, it is imperative that NGOs consider how human rights are interpreted in a local context and are related to the current value system. Change only happens when the values pursued by NGOs are relevant to local people's situation and own belief system (Morris \& Mueller 1992).

In order to understand NGOs' roles in integrating human rights into CSR discourse, it is necessary to examine the operation of power structures. In a general sense, NGOs are seen as powerless to change the external environment (Hudock 1999), but in terms of Foucauldian power, NGOs can be power holders byinfluencing knowledge (Singh \& Titi 1995). In this paper, knowledge of the human rights framework serves to exert power over a different type of knowledge, which is the philanthropy-centred discourse of CSR.

\section{Role 2 - Participatory and empowering process}

In a human-rights-based approach, both the process and the goal accomplishment are considered to be pivotal (Jonsson 2003). Participation and empowerment are the main components of a rights-guided process (Boesen \& Martin 2007; OHCHR 2006). Although participation cannot be simply defined, agreement has been made that the extent of participation is important. Cornwall (2007) refers to providing information or resources as 'weak and pseudo participation' and taking part in decision-making process and self-initiated actions as 'meaningful and authentic participation'. Empowerment is defined as a process of 'power within', 'power with' and 'power to'. Empowerment is possible only when people are 
aware of the oppressive situation (power within) and able to organize collective action (power with) for bringing out change to alter the situation (power to) (Parpart et al. 2003, p. 4).

The principles of participation and empowerment are hardly new to development discourse (Uvin 2007) and both have been popularised to varying extents and focuses (Cornwall 2007). Even the neoliberal notion of development embraces participation and empowerment, albeit with a focus on their use in an apolitical and managerial way (Kamat 2004) as a means of mobilising local resources to cut costs (Cornwall \& Brock 2005; Hoggett et al. 2008). A human-rights-based approach is expected to restore authentic values of participation and empowerment, which have been misused by the neoliberal framework (Ife 2002).

NGOs are expected to ensure authentic participation and empowerment in the process of raising awareness, building collective identity, developing strategies and forming actions for corporate accountability. NGOs' involvement should not result in disempowering grassroots people by deepening the dependency on external help.

\section{Role 3- Linking to global networks and creating the information flow}

NGOs are more experienced in building networks and coordinating various stakeholders such as community based organisations, other NGOs, UN agencies, academics and the media across the world than are indigenous groups. So they can connect grassroots social movements with global networks (Edwards 1999; O'Faircheallaigh \& Ali 2008). Creating a global network is good for pooling resources and opening up opportunities (Morris \& Mueller 1992). It is also likely for potential participants to join the movement in which many participants are involved. (Sierra 2007). Since a global alliance or network consists of various actors with different capabilities, NGOs are expected to take a bigger burden for smaller local groups (Sandler 2004) and to coordinate various, sometimes conflicting interests. This is for NGOs’ greater accountability, not for their greater power.

Besides, NGOs can draw attention from the media and the international community with a long-lasting relationship and a reputation. The role of the mass media is very important in catching the public eye, spreading relevant knowledge, encouraging people's participation and influencing the way people interpret the issue (Morris and Mueller 1992; Tarrow 1994). Since the media can be biased in favour of the powerful or be obsessed with sensational stories and pictures (Tarrow 1994), NGOs' know-how in dealing with the media may be helpful in preventing social movements from being damaged by the media. Gaining the international community's attention also increases the bargaining power of grassroots social movements. Once validated by the international community such as the United Nations, a local issue can leap into international territory (Tarrow 2005). In this way, NGOs can encourage media scandals and international institutions' recommendation, which are influential in forcing corporations to abandon their bad practices.

In the age of information, information is the key to advocacy. Reliable and accurate data make a movement more powerful by supporting main arguments. Information production and dissemination can be more influential than mass demonstration (Alonso, 2009). For this, information should be collected, analysed, transformed into appropriate forms and disseminated widely (Jordan \& Tuijl 2000). NGOs can help with this. Research 
carried out by NGOs is suggested as adding values to facts (Lewis \& Wallace 2000) and as participatory with diverse techniques (Chambers 1994).

More importantly, NGOs should find their roles in expanding access of local people to information. NGOs can spread information to close the information gap between local people and TNCs (Edwards 1999). As well as conveying information directly, NGOs should develop a mechanism to monitor corporations' practice and to train local people to be whistle blowers and producers of information.

\section{Challenges of shifting CSR discourse through social movements}

There are some inherent challenges of grassroots social movements. Firstly, collective movements can put NGOs' staff and local people in a risky situation (Lindenberg \& Dobel 1999; Uvin 2004). Such a fear is not groundless. Madeley (2008) describes how oppressive measures, involving torture and murder, were taken by the Coca-Cola Company to put pressure on Labourers' Union leaders in India. However, the risk can be reduced and shared by generating global network (Fowler 2007). When grassroots social movements are strongly supported by the international community, it is unlikely that corporations will take violent and repressive measures. Sometimes, risks can be posed by governments which try to lure TNCs into their countries. As a government has the authority to register and to close down NGOs, such a risk is not negligible. Kilby (2004) demonstrates how the Indian government outlawed NGOs' advocacy for challenging existing legal systems, but also notes that limits imposed on NGOs' activities led to stronger activism.

Secondly, the flexibility of TNCs can limit the impact of social movements. TNCs have an ability to choose where to operate (Clark 2003). As a result, social movements may end up with an unintended result. Instead of promoting rights of labourers, consumers and citizens, human rights violations can be transferred to another developing country, where states are not willing to or capable to regulate TNCs. Poor developing countries tend to welcome TNCs in the expectation of job creation, increased foreign exchange reserves and technique transfer (Karp 2014; Madeley 2008). As a result of TNC protection policies, TNCs easily avoid their responsibility or transfer it to small local companies (McIntosh 2003). When faced with grassroots resistance, TNCs can move to another country with fewer regulations and weaker rule of law, described as a 'race to the bottom' (Karp 2014:29). This is why social movements should not be confined to community or national level. When grassroots movements are globally organised with bigger impacts across the border, corporations are likely to realise that there is no place to flee from their accountability.

\section{Conclusion}

Corporations' potential contributions towards development and potential threats to poor people have drawn development NGOs' growing interest in CSR. A number of NGOs have adopted a cooperative strategy thus far in the form of TNC's financial contribution and technical assistance with management tools. This results in donor-driven programs and business-like change of NGOs. In the name of CSR, NGOs have also promoted voluntary regulations. Existing studies reveal that the introduction of codes of conduct and certification systems is not very effective to hold TNCs accountable for their practice, as these are based 
on their voluntary will and rooted in capitalism. These CSR-related activities of NGOs have been centred on philanthropy of corporations and raised awareness of Northern citizens. Serious problems lie in the neglect of local people's voice and agency. These problems also raise questions about the legitimacy of NGOs. Without representing and advocating vulnerable people in developing countries, NGOs' work cannot be legitimised. Put another way, current CSR discourse is ineffective in tackling the fundamental problems of TNCs and in upholding legitimacy of NGOs.

This paper suggests re-framing CSR discourse with human rights issues of concern to grassroots people in developing countries. Human rights may constitute a legal and moral framework that enables people affected by TNCs to fight injustice. Local people have played an important role in changing corporations by claiming their rights as labourers, consumers and citizens. However, their activities have tended to be too localised and too narrowly designed for economic interests. As a result, the impact on corporate changes was limited and collective actions did not last long. The human rights framework can provide core values, principled process and strategies for grassroots social movements. Development NGOs are supposed to take on roles to support human rights-guided social movements. The expected roles include developing visions and social values around human rights, building participatory and empowering process, and appealing for global solidarity through network building and information sharing. NGOs face challenges when enhancing corporate accountability and tackling unfair power relations between TNCs and right holders in developing countries. However, these roles also present an opportunity to NGOs, whose identity and legitimacy have been questioned.

To summarise, the key argument of this paper is threefold: the Northern-driven and philanthropy-centred CSR discourse is contested and challenged in local contexts; an alternative discourse of human-rights-based CSR can be shaped by grassroots people; development NGOs should shift their roles in CSR discourse from cooperative partners of TNCs to facilitators of grassroots social movements to hold TNCs accountable. This paper invites future empirical studies which examine the implications of human-rights-based CSR and assess corporate changes by NGO-supported grassroots movements.

\section{Acknowledgements}

I am grateful to all reviewers who provided constructive comments on earlier versions of this paper.

\section{References}

Aguinis, H. and Glavas, A. 2012, 'What we know and don’t know about corporate social responsibility a review and research agenda', Journal of management, vol.38, no.4, pp. 932968. doi: https://doi.org/10.1177/0149206311436079

Aguirre, D. 2008, The Human Right to Development in a Globalized World, Ashgate, Aldershot.

Alonso, A. 2009, 'Hybrid activism: Paths of globalisation in the Brazilian environmental movement', IDS Working Papers, 332, pp. 1-49. https://opendocs.ids.ac.uk/opendocs/handle/123456789/4154

Andrews, N. 2013, 'Community expectations from Ghana's new oil find: conceptualizing corporate social responsibility as a grassroots-oriented process', Africa Today, vol.60, no.1, pp. 54-75. doi: https://doi.org/10.2979/africatoday.60.1.55 
Arenas, D., Lozano, J. M. and Albareda, L. 2009. 'The role of NGOs in CSR: Mutual perceptions among stakeholders’, Journal of business ethics, vol.88, no.1, pp.175-197. doi:10.1007/s10551009-0109-X.

Blowfield, M. 2005, 'Corporate social responsibility: reinventing the meaning of development?', International Affairs, vol.8, no.3, pp. 515-524. doi: https://doi.org/10.1111/j.14682346.2005.00466.X

Boesen, J. K. and Martin, T 2007, Applying a Rights-Based Approach: An Inspirational Guide for Civil Society, Danish Institute for Human Rights, Copenhagen.

Bond, P. 2008, 'Social movements and corporate social responsibility in South Africa', Development and Change, vol.39, no.6, pp. 1037-1052. doi: https://doi.org/10.1111/j.14677660.2008.00528.x

Borras, S.M., M. Edelman, and Kay C. (eds.) 2008, Transnational Agrarian Movements Confronting Globalization, Wiley-Blackwell, Oxford.

Carroll, A. B. 1991, 'The pyramid of corporate social responsibility: Toward the moral management of organizational stakeholders’, Business Horizons, vol.34, no.4, pp.39-48. doi: https://doi.org/10.1016/0007-6813(91)90005-G

Caruana, R. and Chatzidakis, A. 2014, 'Consumer social responsibility (CnSR): Toward a multi-level, multi-agent conceptualization of the "other CSR”', Journal of Business Ethics, vol.121, no.4, pp. 577-592. doi: https://doi.org/10.1007/s10551-013-1739-6

Chambers, R. 1994. 'Participatory rural appraisal (PRA): Analysis of experience', World Development, vol.22, no.9, pp. 1253-1268. doi: https://doi.org/10.1016/0305-750X(94)90003-5

Clark, J. 2003, Globalizing Civic Engagement: Civil Society and Transnational Action, Earthscan, London.

Clark, J. 1991, Democratizing Development: The Role of Voluntary Organizations, Earthscan, London.

Conroy, M. 2001, Can advocacy-led certification systems transform global corporate practices? Evidence, and some theory, Political Economy Research Institute, University of Massachusetts, Amherst.

Cornwall, A. 2007, 'Buzzwords and fuzzwords: deconstructing development discourse', Development in Practice, vol.17, nos.4-5, pp. 471-484.

Cornwall, A. and Brock, K. 2005, Beyond buzzwords: 'poverty reduction', 'participation' and 'empowerment' in development policy, United Nations Research Institute for Social Development, Geneva.

Dolan, C. and Scott, L. 2009, 'Lipstick evangelism: Avon trading circles and gender empowerment in South Africa’, Gender \& Development, vol.17, no.2, pp. 203-218. doi: https://doi.org/10.1080/13552070903032504

Edwards, M. 1999, Future Positive: International Co-operation in the 21st Century, Earthscan, London.

Edwards, M. and Gaventa, J. 2001, Global Citizen Action, Earthscan, London.

Escobar, A. 1995, Encountering Development: The Making and Unmaking of the Third World, Princeton University Press, Princeton.

Fairclough, N. 1992, Discourse and Social Change, Polity Press, Cambridge.

Foucault, M. 1972, The Archaeology of Knowledge, Pantheon, New York.

Foucault, M. 1978, 'Politics and the study of discourse', Ideology and Consciousness, vol.3, pp. 7-26.

Foucault, M. 1980, Power/knowledge: Selected Interviews and Other Writings 1972-1977. Pantheon Books, New York.

Foucault, M. 1982, 'The subject and power', Critical Inquiry, vol.8, no.4, pp. 777-795. doi: https://doi.org/10.1086/448181 
Fowler, A. 2007, Civic Driven Change and International Development: Exploring a Complexity Perspective, Contextuals, No. 7, Context International Co-operation, Utrecht. http://contextinternationalcooperation.files.wordpress.com/2007/12/contextuals-no-7-civicdriven-change-and-international-development.pdf

Fowler, A. 2005, 'Aid Architecture: reflections on NGDO futures and the emergence of counterterrorism', INTRAC Occasional Paper, 45, pp. 1-39.

Fowler, A., 2000, 'Introduction: NDGO Values and The Fourth Position', in Fowler, A. (ed.), NGO Futures: Beyond Aid, Third World Quarterly Theme Issue, vol. 21, no. 4, pp. 589-604. doi: https://doi.org/10.1093/eurpub/10.suppl_3.1, https://doi.org/10.1017/s095653610011209x, https://doi.org/10.1093/rsq/19.3.1-a and https://doi.org/10.1093/rsq/19.3.1

Fraser, N. 1989, Unruly Practices: Power, Discourse, and Gender in Contemporary Social Theory, University of Minnesota Press, Minneapolis.

Frynas, J. G. 2005, 'The false developmental promise of corporate social responsibility: Evidence from multinational oil companies’, International Affairs, vol.81,no.3, pp.581-598. doi: https://doi.org/10.1111/j.1468-2346.2005.00470.x

Gaventa, J. and Tandon, R. 2010, Globalising Citizens: New Dynamics of Inclusion and Exclusion, Zed Books, London.

Gifford, J. and Ansett, S. 2014 '10 things that have changed since the Bangladesh factory collapse', The Guardian, London 3 April 2014.

Available at: http://www.theguardian.com/sustainable-business/bangladesh-factory-collapse10-things-changed

Gilberthorpe, E. and Banks, G. 2012, 'Development on whose terms?: CSR discourse and social realities in Papua New Guinea's extractive industries sector', Resources Policy, vol.37, no.2, pp. 185-193. doi: https://doi.org/10.1016/j.resourpol.2011.09.005

Habermas, J. 2001, The Postnational Constellation: Political Essays, Polity Press, Cambridge.

Hickey, S. and D. Mitlin, 2009, Rights-Based Approaches to Development: Exploring the Potential and Pitfalls, Kumarian Press, Sterling,VA.

Hilton, M. 2007, 'The consumer movement and civil society in Malaysia', International Review of Social History, vol.52, no.3, pp. 373-406. doi: https://doi.org/10.1017/S0020859007003045

Hoggett, P., Mayo, M. C. and Miller, C. 2008, The Dilemmas of Development Work: Ethical Challenges in Regeneration, Policy Press, Bristol.

Hond, F., Bakker F. and P. Neergaard (Eds.) 2007, Managing Corporate Social Responsibility in Action: Talking, Doing and Measuring, Ashgate, Aldershot.

Hudock, A. 1999, NGOs and Civil Society: Democracy by Proxy?, Polity Press, Cambridge.

Idemudia, U. 2011, 'Corporate social responsibility and developing countries: moving the critical CSR research agenda in Africa forward', Progress in Development Studies, vol.11, no.1, pp. 118. doi: https://doi.org/10.1177/146499341001100101

Ife, J. 2002, Community development, Pearson Education Australia, Frenchs Forest.

International Council on Human Rights Policy, 2002, 'Beyond voluntarism: human rights and the developing international legal obligations of companies'.

Available from: http://www.ichrp.org/files/reports/7/107_report_en.pdf

Jamali, D. 2014, 'CSR in developing countries through an institutional lens', Corporate Social Responsibility and Sustainability: Emerging Trends in Developing Economies, vol.8, pp. 21-44. doi: https://doi.org/10.1108/s2043-905920140000008005

Jonsson, U. 2003, Human Rights Approach to Development Programming, UNICEF ESARO, Nairobi.

Jordan, L. and Tuijl, P.V. 2000, 'Political responsibility in transnational NGO advocacy', World Development, vol.28, no.12, pp. 2051-2065. 
Joseph, J. 2004, Social Theory: an Introduction, New York University Press, New York.

Kamat, S. 2004, 'The privatization of public interest: theorizing NGO discourse in a neoliberal era', Review of International Political Economy, vol.11, no.1, pp.155-176.doi: https://doi.org/10.1080/0969229042000179794

Karp, D. J. 2014, Responsibility for Human Rights: Transnational Corporations in Imperfect States, Cambridge University Press, Cambridge. doi: https://doi.org/10.1017/CBO9781139795418

Kilby, P. 2004, 'Accountability for empowerment: dilemmas facing non-governmental organizations', Policy and governance discussion papers, Asia Pacific School of Economics and Governance, Australian National University, Canberra..

Kovacs, R. 2006. 'Interdisciplinary bar for the public interest: What CSR and NGO frameworks contribute to the public relations of British and European activists', Public Relations Review, vol.32, no.4, pp. 429-431. doi: https://doi.org/10.1016/j.pubrev.2006.09.013

Lewis, D. and Wallace, T. 2000, New Roles and Relevance: Development NGOs and the Challenge of Change, Kumarian Press, Bloomfield, CT.

Lindenberg, M. and Bryant, C. 2001, Going Global: Transforming Relief and Development NGOs, Kumarian Press, Bloomfield, CT.

Lindenberg, M. and Dobel, J. 1999, 'The challenges of globalization for northern international relief and development NGOs’, Nonprofit and Voluntary Sector Quarterly, vol.28, no.4, pp. 4-24. doi: https://doi.org/10.1177/089976499773746401

Lindholm, H., Egels-Zanden, N. and Rudén, C. 2016, 'Do code of conduct audits improve chemical safety in garment factories: Lessons on CSR in the supply chain from Fair Wear Foundation', International journal of occupational and environmental health, vol.22, no.4, pp. 283-291. doi: https://doi.org/10.1080/10773525.2016.1227036

Madeley, J. 2008, Big Business, Poor Peoples: How Transnational Corporations Damage the World's Poor, Zed Books, London.

McHoul, A. and Grace, W. 1993, A Foucault Primer: Discourse, Power, and the Subject, Melbourne University Press, Carlton.

McIntosh, M. 2003. Living Corporate Citizenship: Strategic Routes to Socially Responsible Business, Financial Times Management/Prentice Hall, London.

Middleton, C. and Pritchard, A. 2013, Corporate Accountability in ASEAN: A Human Rights-based Approach, Forum-Asia, Bangkok.

Molina-Gallart, N. 2014, 'Strange bedfellows? NGO-corporate relations in international development: an NGO perspective', Development Studies Research, vol.1, no.1, pp.42-53. doi: https://doi.org/10.1080/21665095.2014.915617

Morris, A. and Mueller, C. 1992, Frontiers in Social Movement Theory, Yale University Press, New York.

Nestlé Public Affairs, 2007, Water Management Report. Available at: http://www.unglobalcompact.org/system/attachments/2037/original/COP.pdf?1262614304

Newell, T. 2004, 'Corporate Social Responsibility and Development: In quest of an agenda', Development, 47(3), pp. 29-36. doi: https://doi.org/10.1057/palgrave.development.1100064

Newell, P. and Wheeler, J. 2006, 'Making Accountability Count; the Rights, Resources and the Politics of Accountability', IDS Policy Briefing Paper 33.

Nyamugasira, W. 1998, 'NGOs and advocacy: how well are the poor represented?', Development in Practice, vol.8, no.3, pp. 297-308. doi: https://doi.org/10.1080/09614529853594

Nyamu-Musembi, C. and Musyoki S. 2004, Kenyan Civil Society Perspectives on Rights, RightsBased Approaches to Development, and Participation, Institute of Development Studies, Brighton. 
O'Faircheallaigh, S. and Ali, S. 2008, Earth Matters: Indigenous Peoples, the Extractive Industries and Corporate Social Responsibility, Greenleaf, Sheffield.

OECD (Organisation for Economic Co-operation and Development), 2001, 'Codes of corporate conduct: Expanded review of their contents’, Working Papers on International Investment, \#2001/6.

Available at: http://www.oecd.org/dataoecd/57/24/1922656.pdf

OHCHR (Office of the UN High Commissioner for Human Rights) 2006, Frequently asked questions on a human rights-based approach to development cooperation, UN, New York and Geneva.

Panitch, L. and C, Leys. 2003, The New Imperial Challenge, Merlin Press, London.

Parpart, J. L., Rai, S.M. and Staudt, K.A. (Eds.) 2003, Rethinking Empowerment: Gender and Development in a Global/Local World, Routledge, Oxford.

Rahman, M. 1993, People's Self-development: Perspectives on Participatory Action Research, Zed Books, London.

Rathert, N. 2016, Strategies of legitimation: MNEs and the adoption of CSR in response to hostcountry institutions, Journal of International Business Studies, vol.47, no.7, pp. 858-879.doi: https://doi.org/10.1057/jibs.2016.19

Sandler, T. 2004, Global Collective Action, Cambridge University Press, Cambridge. doi:

https://doi.org/10.1017/CBO9780511617119

Schirato, T. 2012, Understanding Foucault, Allen \& Unwin, Sydney.

Schwartz, M. S. and Carroll, A. B. 2003, 'Corporate social responsibility: A three-domain approach', Business Ethics Quarterly, vol.13, no.4, pp.503-530. doi: https://doi.org/10.5840/beq200313435

Sen, G. and Edwards, M. 2000, 'NGOs, social change and the transformation of human relationships: a 21st-century civic agenda', Third World Quarterly, vol.21, no. 4, pp. 605-616. doi: https://doi.org/10.1080/713701069

Sierra, L. 2007, A Unified Theory of Collective Action and Social Change, University of Michigan Press, Michigan.

Silverthorne, S. 2007, 'Business and the Global Poor', Harvard Business School Working Knowledge, 5 February 2007, Available at: http://hbswk.hbs.edu/item/business-and-the-global-poor .

Singh, N. and Titi, V. 1995, Empowerment: Towards Sustainable Development, Zed Books London.

Skouloudis, A., Evangelinos, K. and Malesios, C. 2015, 'Priorities and perceptions for corporate social responsibility: an NGO perspective', Corporate Social Responsibility and Environmental Management, vol.22, no.2, pp.95-112. doi: https://doi.org/10.1002/csr.1332

Subba, D. and Rao, M. K. 2016, 'Measuring the Effects of CSR on Compassion at Workplace: An Empirical Study in North East Region of India', Purushartha: A Journal of Management Ethics and Spirituality, vol.9, no.1, pp.26-42.

Tarrow, S. 2005, The New Transnational Activism, Cambridge University Press, Cambridge. doi: https://doi.org/10.1017/CBO9780511791055

Tarrow, S. 1994, Power in Movement: Social Movements, Collective Action and Politics, Cambridge University Press, New York.

Thekdi, S. A. 2016, 'Risk management should play a stronger role in developing and implementing social responsibility policies for organizations’, Risk Analysis, vol.36, no.5, pp. 870-873. doi: https://doi.org/10.1111/risa.12643

Thompson, L. and Tapscott, C. 2010, Citizenship and Social Movements: Perspectives from the Global South, Zed Books, London.

Unerman, J. and B. O'Dwyer, 2006, 'Theorising accountability for NGO advocacy', Accounting, Auditing \& Accountability Journal, vol.19, no.3, pp. 349-376. doi: https://doi.org/10.1108/09513570610670334 
Uvin, P. 2004, Human Rights and Development, Kumarian Press, Bloomfield, CT.

Uvin, P. 2007, 'From the right to development to the rights-based approach: How 'human rights' entered development', Development in Practice, vol.17, nos.4-5, pp. 597-606. doi: https://doi.org/10.1080/09614520701469617

Visser, W. 2006, Revisiting Carroll's CSR pyramid, cited in Pedersen, E. R. and Huniche, M. 2006, Corporate Citizenship in Developing Countries, Copenhagen Business School Press, Copenhagen.

Waddock, S. 2009, ‘Making a difference?’, Journal of Corporate Citizenship, vol.33, pp. 35-46. doi: https://doi.org/10.9774/GLEAF.4700.2009.sp.00007

Wetherell, M., Taylor, S. and Yates, S. J. 2001, Discourse Theory and Practice: A Reader, Sage, London.

Yu, X. 2009, 'From passive beneficiary to active stakeholder: Workers' participation in CSR movement against labor abuses', Journal of Business Ethics, vol.87, no.1, pp. 233-249. doi: https://doi.org/10.1007/s10551-008-9815-z 